\title{
Taguchi Optimization for Nickel-Cobalt Extraction Process using Cyanex 272 from Laterite
}

\author{
Sudibyo, A Junaedi, A Aziza, and P Manurung
}

\begin{abstract}
A research on the Optimization of Nickel-Cobalt Extraction Process using Cyanex 272 from Laterit with Taguchi Method. The process of separation of nickel from other impurities can be done by sulfuric acid leaching method and Hydrochloric acid leaching and extraction system. The study design was prepared using the Taguchi-Larger the Better Method. Characterization of laterite nickel raw materials using X-Ray Diffraction (XRD), leaching results using X-Ray Fluorescence (XRF) and extraction results using Atomic Absorption Spectrophotometric (AAS). The optimum condition of leaching and cobalt extraction process using Cyanex 272 from laterite was obtained with leaching time parameter $=8$ hours, volume of Cyanex $272=10 \% \mathrm{v} / \mathrm{v}, \mathrm{H} 2 \mathrm{SO} 4$ concentration $=$ $6 \mathrm{M}$. The higher concentration of $\mathrm{H} 2 \mathrm{SO} 4$ leaching process, the percentage of cobalt obtained The higher, Co will remain in the aqueous solution at low $\mathrm{pH}<2$ in the process of dissolving the laterite ore.
\end{abstract}

Keyword:Nickel-Cobalt Extraction, Cyanex 272, Taguchi, laterite

\section{INTRODUCTION}

Indonesia has abundant mineral resources so it has great potential as a producer of minerals based chemicals. Indonesia is a country rich in mineral resources, one of which is lateritic nickel ore, where it is estimated that nickel laterite ore reserves in Indonesia reaches 1.391 billion tons, which is $4.9 \%$ of the world's nickel laterite ore deposit, or ranks eighth largest In the world [1].

However, this abundant natural wealth has not been utilized for the production of chemicals. The chemicals used in Indonesia are partly from overseas which are sold at very high prices. When in fact if we process the ore-ore minerals in this country, it will greatly help save costs incurred for the purchase of chemicals.

The need for mineral-based chemicals at home and abroad is enormous to support the research, laboratory,

Manuscript received August 23, 2017. This work was supported from Indonesian Institute of Sciences and Ministry of Research, Technology and Higher Education - The Republic of Indonesia through INSINAS research grant no. RT-2016-0227.

Sudibyo is with the research unit for mineral technology - Indonesian Institute of Sciences, Lampung province, Indonesia (e-mail: sudibyo@lipi.go.id).

A. Juanedi is electrical engineer in the research unit for mineral technology - Indonesian Institute of Sciences, Lampung province, Indonesia (e-mail: sayannga1@gmail.com)

A. Aziza is with Physics department, Mathematic and Sciences Faculty, Lampung university, lampung province, Indonesia (e-mail: auliaaziza.rois@gmail.com).

$\mathrm{P}$ Manurung is with the Physics department, Mathematic and Sciences Faculty, Lampung university, lampung province, Indonesia (e-mail: posman.manurung@unila.ac.id). industrial, pharmaceutical, anti-rust metals, blends in the manufacture of stainless steel, nickel metal hybrid batteries [2], aircraft industry, Armor plating, and various other functions [3].

This cultivation also makes nickel very valuable and has a high selling value in the world market. At least since 1950 the demand for nickel averaged an increase of $4 \%$ per year, and is expected to increase in the next ten years [2].

This research was optimized using Taguchi method, with Taguchi method will get the optimization value and will reduce the number of experiments. This study studied the effect of leaching time parameter, $\mathrm{H}_{2} \mathrm{SO}_{4}$ concentration, a volume of Cyanex 272 to increase of the percentage of Co [4]. Each parameter has 3 levels so with Taguchi method it only takes 9 experiments. If not using Taguchi method will require 27 experiments.

\section{PROCEDURE}

The materials used are Laterite Ore, laterite ores used from Southeast Sulawesi, Sulfuric Acid $\left(\mathrm{H}_{2} \mathrm{SO}_{4}\right)$, Cyanex 272, Toluene. Analytical tools used are XRF, AAS, XRD.

This research consists of two stages namely the process of leaching and extraction.

The leaching process begins with preparing the raw material, then analyzing the laterite nickel raw material using XRD. The lateritic nickel raw material used by each experiment is $20 \% \mathrm{w} / \mathrm{v}$. Thereafter mixing the laterite nickel with sulfuric acid solution with variations of 4, 5 and $6 \mathrm{M}$. The mixture of laterite nickel with sulfuric acid solution is stirred with a magnetic stirrer and hotplate at $90{ }^{\circ} \mathrm{C}$. at a stirring rate of $500 \mathrm{rpm}$ and at atmospheric pressure for a time variation of 4, 8, 12 hours. Leaching results are divided into 2 ie liquid and solids. The resulting leaching solids were analyzed using XRF (Olympus XRF portable).

In the extraction process, Cyanex 272 was diluted using toluene with volume variations of $10,15,20 \% \mathrm{v} / \mathrm{v}$. Furthermore, the liquid leaching results are mixed with a solution of Cyanex 272 and shook as much as 500 beats to 2 phase apart from the aqueous phase and organic phase. Furthermore, aqueous phase extraction results were analyzed by AAS (AA-7000 Shimadzu). 
TABLE 1. DESIGN OF EXPERIMENT USING TAGUCHI METHOD AND ITS RESULS

\begin{tabular}{|c|c|c|c|c|}
\hline \multirow[b]{2}{*}{$\begin{array}{c}\text { No. } \\
\text { Experiment }\end{array}$} & \multicolumn{3}{|c|}{ Experiment } & \multirow[b]{2}{*}{$\begin{array}{c}\text { Result } \\
\text { The } \\
\text { increase of } \\
\text { Co } \\
\text { Percentage } \\
(\%)\end{array}$} \\
\hline & $\begin{array}{l}\text { Leaching } \\
\text { Time } \\
\text { (Hour) }\end{array}$ & $\begin{array}{c}\text { Volume } \\
\text { of } \\
\text { Cyanex } \\
272 \\
(\% \mathrm{~V} / \mathrm{V})\end{array}$ & $\begin{array}{c}\mathrm{H}_{2} \mathrm{SO}_{4} \\
\text { Concentration } \\
(\mathrm{M})\end{array}$ & \\
\hline 1 & 4 & 10 & 4 & 1829.08 \\
\hline 2 & 4 & 15 & 5 & 799.29 \\
\hline 3 & 4 & 20 & 6 & 899.57 \\
\hline 4 & 8 & 10 & 5 & 1500.91 \\
\hline 5 & 8 & 15 & 6 & 1776.67 \\
\hline 6 & 8 & 20 & 4 & 1475.86 \\
\hline 7 & 12 & 10 & 6 & 2119.49 \\
\hline 8 & 12 & 15 & 4 & 440.03 \\
\hline 9 & 12 & 20 & 5 & 1420.33 \\
\hline
\end{tabular}

\section{RESEARCH RESULT AND DISCUSSION}

A. Characterization Nickel Laterite Raw Materials using $X R D$

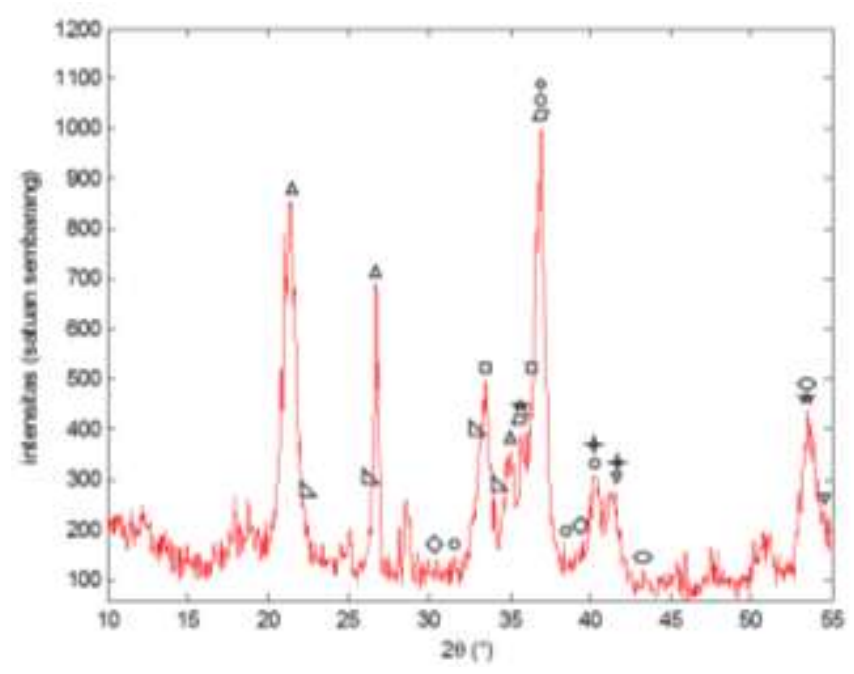

Fig. 1. Diffraction of nickel laterite raw material $\left(2 \theta=10-55^{\circ}, \lambda=1,541 \AA\right)$ Legends:

$\Delta=\mathrm{FeOOH}$ (Geothite).

口 $=\mathrm{Fe}_{2} \mathrm{O}_{3}$ (Hematite).

$\diamond=\mathrm{Co}_{2} \mathrm{O}_{3}$ (Cobalt Oxide).

$\mathrm{O}=\mathrm{Al}_{2} \mathrm{O}_{3}$ (Alumunium Oxide).

$\square=\mathrm{Fe}_{3} \mathrm{O}_{4}$ (Magnetite).

$\nabla=\mathrm{Cr}_{2} \mathrm{O}_{3}$ (Chromium Oxide).

$\bigcirc=\mathrm{FeNi}$ (Ferro Nikel).

$\star \quad=\mathrm{CoFe}_{2} \mathrm{O}_{4}$ (Cobalt Ferrite).

$\Delta \quad=\mathrm{SiO}_{2}$ (Silicon Oxide).

$\downarrow \quad \mathrm{MgO}$ (Magnesium Oxide).

Figure 1 shows the diffraction of nickel laterite raw materials. When $2 \Theta$ denotes the value of $21.38^{\circ}$ Geothite phase is formed with $\mathrm{FeOOH}$ molecular formula at 852.3 intensity and $d$ value 4,1561 [PDF\#290713]. When $2 \Theta$ denotes a value of $21.892^{\circ}$ formed a Silicon Oxide phase with the formula of $\mathrm{SiO}_{2}$ molecules at an intensity of 165.5 and a d value of 4.41 [PDF\#470718]. When $2 \Theta$ shows a value of $26.266^{\circ}$ formed a Silicon Oxide phase with the formula of $\mathrm{SiO}_{2}$ molecules at an intensity of 283.9 and a $\mathrm{d}$ value of 3.3932 [PDF\#470718]. When $2 \Theta$ shows a value of $26.68^{\circ}$ Geothite phase is formed with the $\mathrm{FeOOH}$ molecular formula at an intensity of 677.5 and a d value of 3.3413 [PDF\#260792]. When $2 \Theta$ shows the value of $31,164^{\circ}$ Cobalt Oxide phase formed with formula molecule $\mathrm{Co}_{2} \mathrm{O}_{3}$ at intensity 118,1 and value d equal 2,8696 [PDF\#020770]. When $2 \Theta$ shows a value of $32.806^{\circ}$ formed Aluminum Oxide phase with $\mathrm{Al}_{2} \mathrm{O}_{3}$ molecular formula at 227.9 intensity and $\mathrm{d}$ value of 2.73 [PDF\#350121]. When $2 \Theta$ shows a value of $33.155^{\circ}$ formed a Silicon Oxide phase with a $\mathrm{SiO}_{2}$ molecular formula at an intensity of 309.7 and a d value of 2.702197 [PDF\#471300]. When $2 \Theta$ shows the value of $33,40^{\circ}$ Hematite phase formed with the formula molecule $\mathrm{Fe}_{2} \mathrm{O}_{3}$ at intensity 442,1 and d value equal to 2,6828 [PDF\#060502]. When $2 \Theta$ shows a value of $34.565^{\circ}$ formed a Silicon Oxide phase with the formula $\mathrm{SiO}_{2}$ molecule at 246.2 intensity and a $\mathrm{d}$ value of 2.595 [PDF\#461242]. When $2 \Theta$ shows a value of 35.266 formed a Geothite phase with $\mathrm{FeOOH}$ molecular formula at 246.2 intensity and a d value of 2.5451 [PDF\#130518]. When $2 \Theta$ shows a value of $35.467^{\circ}$ phase formed Cobalt Ferrite with the molecular formula $\mathrm{CoFe}_{2} \mathrm{O}_{4}$ at an intensity of 250.3 and a value of $2.53015 \mathrm{~d}$ [PDF\#030862]. When $2 \Theta$ shows a value of $35.482^{\circ}$ formed Magnetite phase with $\mathrm{Fe}_{3} \mathrm{O}_{4}$ molecular formula at the intensity of 250.3 and a value of 2.53 [PDF\#060502]. When $2 \Theta$ shows the value of $35,715^{\circ}$ formed Hematite phase with $\mathrm{Fe}_{2} \mathrm{O}_{3}$ molecule formula at intensity 353,4 and d value equal to 2,514 [PDF\#251402]. When $2 \Theta$ shows the value of $36.95^{\circ}$ Magnetite phase formed with the formula molecule $\mathrm{Fe}_{3} \mathrm{O}_{4}$ [PDF\#290713], Aluminum Oxide $\left(\mathrm{Al}_{2} \mathrm{O}_{3}\right)$ [PDF\#110517] and Cobalt Oxide $\left(\mathrm{Co}_{2} \mathrm{O}_{3}\right)$ [PDF\#021079] at the intensity of 993.5 and the value of $d$ 2,4309 . When $2 \theta$ shows a value of $37.538^{\circ}$ formed Aluminum Oxide phase with $\mathrm{Al}_{2} \mathrm{O}_{3}$ molecular formula at the intensity of 158.5 and a d value of 2.3061 [PDF\#471292]. When $2 \Theta$ shows the value of $38,643^{\circ}$ Cobalt Oxide phase formed with a molecular formula of $\mathrm{Co}_{2} \mathrm{O}_{3}$ at intensity 144,4 and value d equal 4,6582 [PDF\#020770]. When $2 \Theta$ shows a value of $40.18^{\circ}$ formed Aluminum Oxide phase with $\mathrm{Al}_{2} \mathrm{O}_{3}$ and Magnesium Oxide $(\mathrm{MgO})$ molecular formula at an intensity of 306.8 and a d value of 2.2444 [PDF\#120539]. When $2 \Theta$ shows the value of $41,26^{\circ}$ formed Chromium Oxide phase with formula molecule $\mathrm{Cr}_{2} \mathrm{O}_{3}$ and Magnesium Oxide $(\mathrm{MgO})$ at intensity 270,3.

\section{B. Optimum Condition of Extraction Process}

The percentage increase of Co in the Aqueous phase of the nickel laterite ore extraction process is presented in Table 1. While the percentage of $\mathrm{Ni}$ in the Organic phase increases and the Aqueous phase decreases. In this study, the effect of leaching time, Cyanex 272 volume, $\mathrm{H}_{2} \mathrm{SO}_{4}$ concentration on Co percentage increase in Aqueous phase optimized using Signal-to-Noise (SN) -Ratio Taguchi-Larger the Better method.

Based on the result of analysis using Taguchi method shown in Table 2, optimum condition of Co extract is obtained with leaching time parameter is at 8 hours, Cyanex 272 volume is at $10 \% \mathrm{v} / \mathrm{v}, \mathrm{H}_{2} \mathrm{SO}_{4}$ concentration is at $6 \mathrm{M}$.

Table 3 shows the results of SN Ratio analysis on each parameter using Taguchi larger the better analysis method. From each parameter, there is a Delta value which is the difference between the highest and lowest values of the SN Ratio and the average on each parameter. The highest delta values show the best ratings. The first rank of parameter which affected the percentage of cobalt increment is volume of Cyanex 272. Meanwhile the second and third rank are the $\mathrm{H}_{2} \mathrm{SO}_{4}$ concentration and leaching duration, respectively. 
TABLE 2.

RESUltS OF SN RATIO TAGUCHI METHOD LARGER THE BETTER TO CO PERCENTAGE INCREASE IN AQUEOUS PHASE

\begin{tabular}{cccc}
\hline Level & $\begin{array}{c}\text { Leaching } \\
\text { Time } \\
\text { The increase } \\
\text { of Co } \\
\text { Percentage } \\
(\%)\end{array}$ & $\begin{array}{c}\text { Volume of } \\
\text { Cyanex 272 } \\
\text { (The increase } \\
\text { of Co } \\
\text { Percentage }(\%)\end{array}$ & $\begin{array}{c}\text { Concentration } \\
\text { The increase of } \\
\text { Co Percentage } \\
(\%)\end{array}$ \\
\hline 1 & 60.79 & 65.10 & 60.50 \\
2 & 63.97 & 58.64 & 60.75 \\
3 & 60.81 & 61.84 & 62.88 \\
Delta & 3.17 & 6.46 & 3.50 \\
Optimum & 2 & 1 & 3 \\
Level & 3 & 1 & 2 \\
Ranking & & & \\
\hline
\end{tabular}

C. The Effect of $\mathrm{H}_{2} \mathrm{SO}_{4}$ Concentration Towards The Increase of Co Percentage

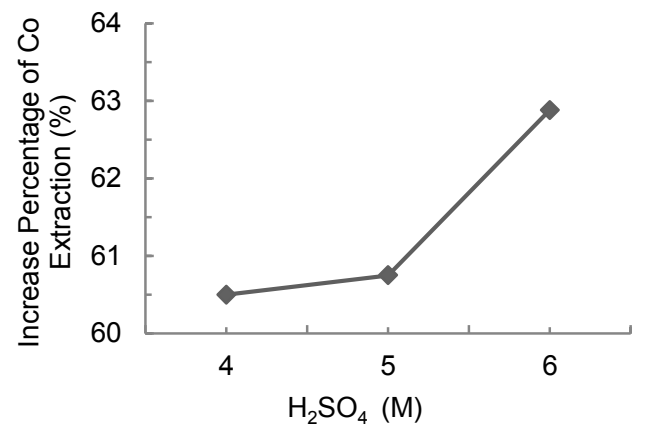

Fig. 2. The effect of $\mathrm{H} 2 \mathrm{SO} 4$ concentration towards the increase of Co percentage.

Figure 2shows that the highest increase of Co percentage is obtained when leaching process using sulfuric acid with $6 \mathrm{M}$ concentration got $62.88 \%$ of the increase of $\mathrm{Co}$ percentage . The higher concentration of sulfuric acid gives a higher value of the increase of Co percentage . Cobalt is an element that is insoluble in water, but able to dissolve in acidic conditions.

\section{The Effect of Leaching Duration Towards The Increase of Co Percentage}

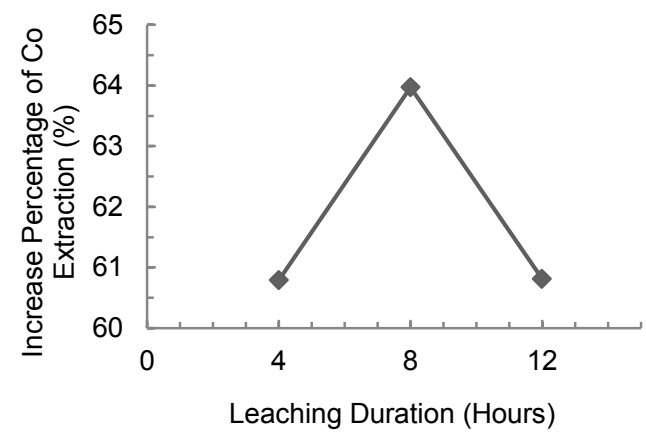

Fig. 3. The effect of leaching duration (hours) towards the increase of Co percentage.

The length of leaching time is one of the factors affecting the dissolution process of Cobalt in sulfuric acid solution. The longer the leaching time will be the more dissolved metal ions.Figure 3 shows that the highest increase percentage of Co extraction is obtained when leaching time with 8 hours got $63.97 \%$ of the increase of Co percentage. At that time, the cobalt ions will be much dissolved in the sulfuric acid solution so that the cobalt extracted in the aqueous solution is more numerous. If the leaching process continues for up to 12 hours then the metal ions other than cobalt will also be more dissolved, this causes the percentage of cobalt extraction to decrease.

\section{E. The Effect of the Cyanex 272 Towards The Increase of Co Percentage}

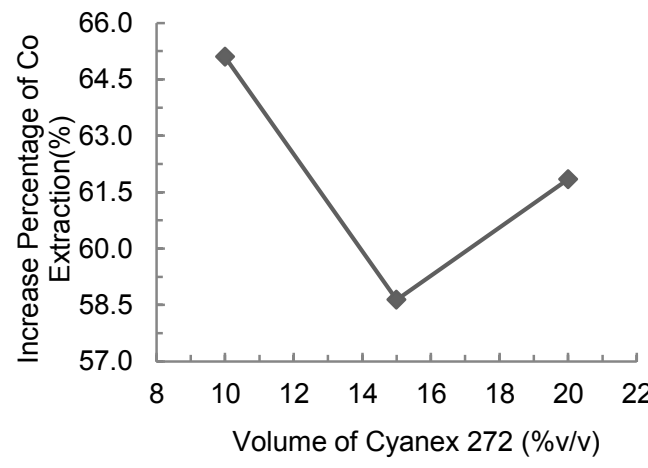

Fig. 4. The effect of Cyanex $272(\% \mathrm{v} / \mathrm{v})$ towards the increase of Co percentage.

Figure 4 shows that the optimum value of Cyanex 272 is at a concentration of $10 \% \mathrm{v} / \mathrm{v}$ obtained $65.10 \%$ of the increase of Co percentage. At these concentrations are the optimum conditions in which metal ions such as Nickel and certain other metals will be extracted into an organic solvent. So that left in aqueous solution is the metal ion of Cobalt and other metal ions ( $\mathrm{Fe}, \mathrm{Mn}, \mathrm{Co}, \mathrm{Zn}, \mathrm{Cu}, \mathrm{In}, \mathrm{Pb}$ ), this causes the cobalt concentration in the aqueous solution to reach the optimum point.

\section{CONCLUSIONS}

From the research it is found that the optimum condition of in cobalt extraction process using Cyanex 272 from laterite is at leaching time of 8 hours, $10 \% \mathrm{v} / \mathrm{v}$ of Cyanex 272 and 6 $\mathrm{M}$ of $\mathrm{H}_{2} \mathrm{SO}_{4}$. The co will remain in the aqueous solution at $\mathrm{pH}$ $<2$ in the process of dissolving the laterite ore. The first, second and third rank of parameters which affected the percentage of cobalt increment are volume of Cyanex, the $\mathrm{H}_{2} \mathrm{SO}_{4}$ concentration and leaching duration, respectively.

\section{REFERENCES}

[1] Nurhakim, M. U., Dwiatmoko, N. H. Romla, M. Adip, “Identification of laterite resources in the middle of sebuku island of south Kalimantan". Info Teknik. 12(2): 48-53, 2011.

[2] Dalvi, A. D., Bacon, W. G., dan Osborn, R. C., " The Past and The Future of Nikel Laterite". Canada: Inco Limited. Pp 575, 2004.

[3] Bradley, K. , "Nickel Applications \&Use"s. Shanghai: 8th Annual China Nickel Conference. Pp 36, 2011.

[4] S. G. Alexandre SG, S. S. Priscila SS, B. M. Marcelo, "Purification of nickel from multicomponent aqueous sulfuric solutions by synergistic solvent extraction using Cyanex 272 and Versatic 10". Hydrometallurgy 150, pp. 173-177, 2014.
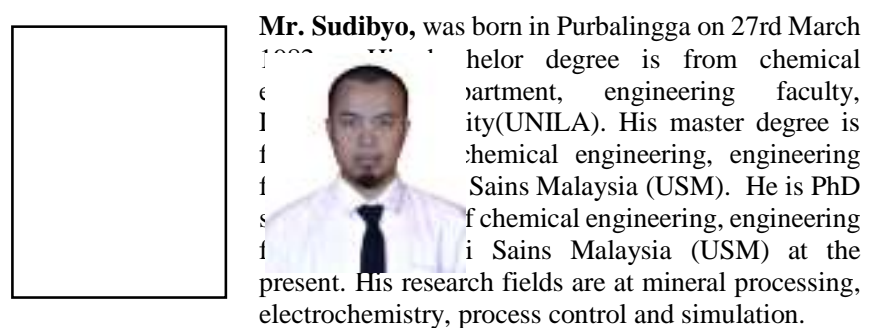

He has experience as chief of production department of Golden sari Chemical Co. 1td., manufacturer of sodium cyclamate at 2006-2007. He was a research assistant in process control laboratory, University Sains Malaysia 
(2007-2015). Now, he is a researcher at research unit of mineral technology , Indonesian institute of sciences.
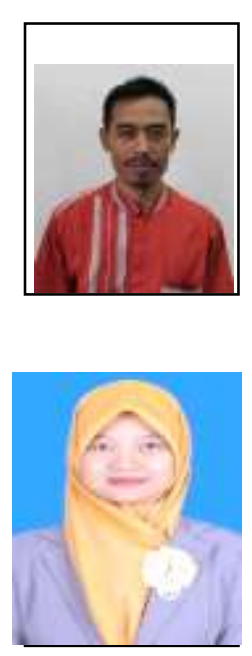

Aulia Aziza was born in Jakarta on October 30, 1994 The author as a bachelor degree student at the Department of Physics, University of Lampung. She conducted the final year project at research unit for mineral technology - Indonesian Institute of sciences (LIPI).

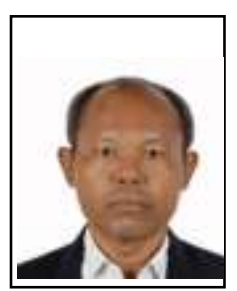

Prof. Drs. Posman Manurung, M.Si., Ph.D. was born in Sionggang on 8 Maret 1959. He is lecturer in Phisics department, Lampung University, Lampiung,Indonesia (UNILA). He also head of master program degree on his department. He get full professor on 2013. His research field is materials, nano technology, material characteristic and thin film. 